\title{
The Importance of Riparian Forest Cover to the Ecological Status of Agricultural Streams in a Nationwide Assessment
}

\author{
Mikko Tolkkinen $^{1}$ (D) $\cdot$ Saku Vaarala ${ }^{1} \cdot J^{\prime} u k k a$ Aroviita ${ }^{1}$
}

Received: 10 February 2021 / Accepted: 10 August 2021 / Published online: 3 September 2021

(c) The Author(s) 2021

\begin{abstract}
Forested riparian corridors are a key management solution for halting the global trend of declining ecological status of freshwater ecosystems. There is an increasing body of evidence related to the efficacy of these corridors at the local scale, but knowledge is inadequate concerning the effectiveness of riparian forests in terms of protecting streams from harmful impacts across larger scales. In this study, nationwide assessment results comprising more than 900 river water bodies in Finland were used to examine the importance of adjacent land use to river ecological status estimates. Random forest models and partial dependence functions were used to quantify the independent effect of adjacent land use on river ecological status after accounting for the effects of other factors. The proportion of adjacent forested land along a river had the strongest independent positive effect on ecological status for small to medium size rivers that were in agricultural landscapes. Ecological quality increased by almost one status class when the adjacent forest cover increased from 10 to $60 \%$. In contrast, for large rivers, adjacent forested land did not show an independent positive effect on ecological status. This study has major implications for managing river basins to achieve the EU Water Framework Directive (WFD) goal of obtaining good ecological status of rivers. The results from the nationwide assessment demonstrate that forested riparian zones can have an independent positive effect on the ecological status of rivers, indicating the importance of riparian forests in mitigating the impacts of catchmentlevel stressors. Therefore, forested buffer zones should be more strongly considered as part of river basin management.
\end{abstract}

Keywords Environmental assessment · Riparian forests $\cdot$ Buffer zone $\cdot$ Streams $\cdot$ Water framework directive $\cdot$ Water bodies

\section{Introduction}

The ecological status of freshwater ecosystems has degraded worldwide, requiring urgent management efforts and policy actions to counter the prevailing trend (Grizzetti et al. 2017; Reid et al. 2019). Agriculture is among the most influential and widespread

Mikko Tolkkinen

mikko.tolkkinen@syke.fi

1 Finnish Environment Institute, Freshwater Centre, PO Box 413, Oulu 90014, Finland 
human-induced land uses affecting freshwater ecosystems (Davies et al. 2009; Flavio et al. 2017). An important mitigation action to counter the negative effects of agricultural land use on the ecological status of freshwater is to maintain or restore forested buffer zones along water courses (e.g., Singh et al. 2021; Cole et al. 2020; Pavlidis and Tsihrintzis 2018; Stutter et al. 2012). Forested riparian zones form a natural buffer adjacent to streams, and they are important for achieving good water quality and maintaining high biodiversity levels (e.g., Naiman et al. 2010). However, evaluations of the importance of forested buffers on ecological status in large river assessments are lacking, which is a significant knowledge gap regarding the efficient implementation of environmental policies such as the European Union Water Framework Directive (WFD, European Commission 2000).

Most freshwater ecosystems are intimately coupled with adjacent riparian areas through lateral and longitudinal fluxes of organisms, matter and energy (Nakano and Murakami 2001; Soininen et al. 2015). Riparian forests play an important role in river ecosystems, for example, by supplying coarse organic material to stream food webs, as well as by regulating stream metabolism and nutrient cycling associated with shading (Perkins et al. 2010; Johnson and Almlof 2016; Warren et al. 2016). Forested riparian zones could also help mitigate climate warming effects on freshwater biotas (Sponseller et al. 2001; Thomas et al. 2016; Turunen et al. 2021) and contribute to the retention of excess nutrients, contaminants and organic material originating from human land use in a catchment (e.g., Kiffney et al. 2003).

The influence of forested buffer zones on rivers in human-influenced catchments has been studied previously. However, our understanding of whether management actions should aim at local reach or catchment scales is inadequate at present. Some studies emphasize the importance of catchment land use, while others suggest that land use adjacent to a river is more important to the structure and function of stream ecosystems (Jones et al. 1999; Lammert and Allan 1999; Death and Collier 2010; Wahl et al. 2013). Forested buffer zones may be most suitable in stream systems that are under moderate agricultural land use (Turunen et al. 2019). In such streams, forested zones may contribute to the retention of excess nutrients, contaminants and organic materials, whereas in streams draining catchments with intense agricultural actions, the potential positive effect of forested zones is not adequate to mitigate ecological degradation (Wahl et al. 2013; Feld et al. 2018).

The importance of land use adjacent to streams may be further associated with stream size. It can be assumed that the positive effects of riparian forests on ecological status should be more pronounced in low-order streams than in larger rivers. This is because of differences in allochthonous and autochthonous primary energy sources between small streams and larger rivers, which is the basic tenet of the river continuum concept (Vannote et al. 1980). Some previous studies have addressed the importance of forested buffers to small streams owing to shading effects (Greenwood et al. 2012; Burdon et al. 2020), thereby supporting the idea that land uses adjacent to a stream are more significant in smaller streams than in larger rivers. Furthermore, for rivers that have large catchment areas, forested zones may not be able to mitigate the effect of agricultural land use on ecological quality. In large rivers, catchment-scale anthropogenic pressures may diminish the positive effects of forested zones on ecosystem structure and function. Hence, it is important to understand how stream size and agricultural land use gradients interact to determine the effect of forested buffer zones on ecological quality. 


\subsection{Hyphotesis}

In this study, we examined the importance of the proportion of forested, non-agricultural land (forested buffer zones) on the ecological status estimates of river water bodies in Finland. The study tested whether forest cover adjacent to a stream or catchment-scale forest cover would be more strongly associated with the ecological status of rivers. We assumed that at a given level of agricultural pressure, increasing the percentage of forested land adjacent to rivers would have a positive effect on their ecological status. In this study, we further assumed that in comparison to the proportion of forest in the entire catchment area, forested buffer zones would be more important to ecological status. The expectation was that the effect of forested buffer zones on ecological status would be more comprehensive in rivers suffering from moderate to high agricultural pressures. We also expected that forested zones would be more important in small and medium streams than in large rivers.

\section{Materials and Methods}

\subsection{Study Dataset}

The study area encompasses most of the Finland mainland $\left(60^{\circ}\right.$ to $65^{\circ} \mathrm{N}, 20^{\circ}$ to $\left.32^{\circ} \mathrm{E}\right)$ but excludes northern Finland. In general, the main anthropogenic land use in southern and western Finland is associated with agriculture, whereas forestry is a more important land use type than agriculture in central and eastern Finland (Fig. 1). Northern Finland was excluded from this study because agricultural pressure is generally low in the area.

The study used data from the Finnish National Freshwater Assessment from the third cycle of WFD river basin management planning. These data are available in a public database maintained by the Finnish Environment Institute (SYKE, https://www.syke.fi/en-US/ Open_information). The assessment includes all major river water bodies and a portion of small rivers across the country $(N=1911)$. The river water bodies are delineated as channel stretches, which are the spatial units used in planning WFD river basin management. Excluding northern Finland, the study included 924 river water bodies that were consistently classified based on ecological, physicochemical and hydromorphological status (see below how ecological status is classified in the WFD). The data represent a large gradient in river size, with catchment areas varying from 0.7 to $40,756 \mathrm{~km}^{2}$ (median $133 \mathrm{~km}^{2}$ ). The river stretch length ranged from 0.14 to $187.7 \mathrm{~km}$ (median: $12.5 \mathrm{~km}$ ).

The ecological status classifications in the context of the WFD are official estimates of the ecological quality of water bodies that are widely used in river basin management and are legally binding environmental objectives of good status for all freshwater bodies. Ecological status incorporates estimates of anthropogenic biological quality impairment (i.e., based on macrophytes, phytobenthos, invertebrates and fish), as well as assessments of alterations in physico-chemical, hydrological and morphological conditions, which are compared to their least-disturbed reference conditions (e.g., Birk et al. 2012; Poikane et al. 2015). Ecological status is classified into five classes, i.e., high, good, moderate, poor and bad, which describe the extent of deviation of biological quality elements from their least-disturbed river-type specific reference conditions. The best status (high) corresponds to reference conditions, whereas in the good status class, slight deviations from reference conditions are allowed. In the moderate status class, deviations have to be moderate, and in 

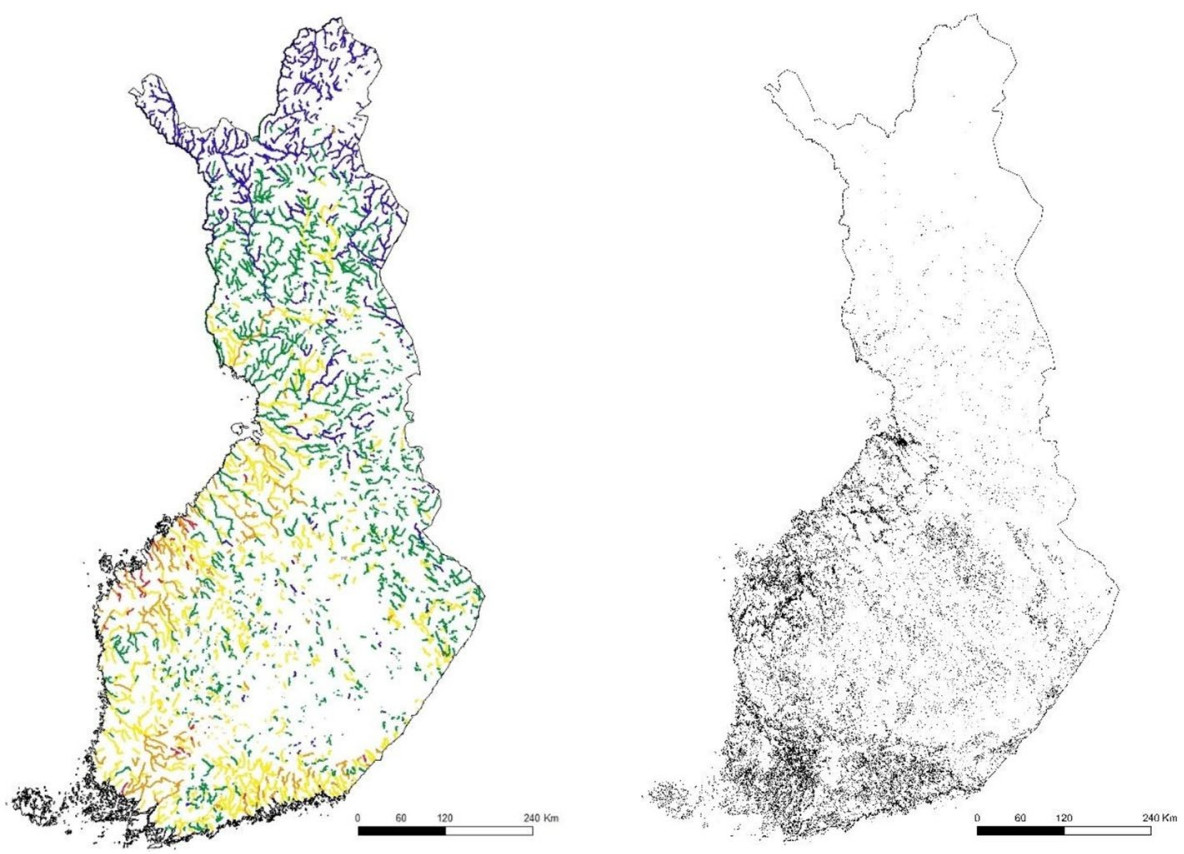

Fig. 1 Map of the study area, showing the river water bodies and the ecological status (left picture) ( $\mathrm{bad}=\mathrm{red}$, poor $=$ orange, moderate =yellow, good=green, and high=blue), and agricultural land use (black) in Finland (right picture) (Ecological Status and Corine Land Cover: Finnish Environment Institute 2021)

the poor status class, deviations are substantial. In bad status class, deviations are severe. In this study, ecological status estimates were performed by regional water authorities to spatially represent a whole water body (i.e., river stretch) between 2012 and 2017 using all available monitoring data and expert knowledge about the status following national guidance (Aroviita et al. 2019).

This study used land cover data for adjacent stream zones and entire catchments for all water bodies using ArcGIS. The adjacent stream zone polygons were delineated as $50-\mathrm{m}$ buffers around the channel line, or in the case of larger rivers, they were delineated with digitalized water areas. The catchment polygons were based on national third division level catchments. We then calculated the relative coverage (\%) of land cover types (CORINE 2012 20*20 m national raster data level 4; (http://geoportal.ymparisto.fi/meta/julkinen/ dokumentit/CorineLandCover2012_en.pdf) for all adjacent stream zones in each catchment. All land cover types, including forested land (CORINE classes 2441-3133), were merged to form the 'forest type', whereas 'agricultural fields' comprised cultivated areas and pastures (CORINE classes 2111-2312).

\subsection{Statistical Methods}

In this study, we used Random Forest (RF) (Breiman 2001) to model the individual effects of riparian land use and catchment-level land use on river ecological status. Random Forests is known to be able to handle complex relationships between response and predictor 
variables. Random Forests is a combination of tree predictors such that each tree depends on the values of a random vector sampled independently, with the same distribution for all trees in the forest (Breiman 2001). Two outputs of the method were used: (1) the relative importance of the predictor variables, which shows the variables included in the model in the order of relative importance in explaining variation in the response variable, and (2) partial dependency plots, which show the directions and forms of the relationships between the response and predictor variables (Zhao and Hastie 2021). The partial dependency plots show the individual effect of each of the predictor variables on the response variable after accounting for the effect of the other predictor variables on the response variable.

In this study, separate RF regression models were built for three different catchment sizes $\left(<100 \mathrm{~km}^{2}, 100-1000 \mathrm{~km}^{2}\right.$, and $\left.>1000 \mathrm{~km}^{2}\right)$ and for three agricultural land use classes ( $<10 \%$ agricultural land use, 10-20\% agricultural land use, and $>20 \%$ agricultural land use) to a priori control for and compare the relationships among varying river sizes and levels of agricultural pressure. Although the study controlled for the effect of agricultural land use using three different agricultural land use classes, agricultural land use percentage was also included as a predictor variable to explore how the agricultural land use gradient was related to ecological status within each of these classes. Because of the complexity of the response-predictor variable relationships in nature, hydromorphological degradation was also used in the analysis and considered a nonlinear relationship between water body ecological status and the predictor variables.

Regression mode of Random Forest was used to explore the variation in ecological status using agricultural field percentage in the catchment, forest percentage in the 50 -m buffers, forest percentage in the catchment, and scores of hydromorphological alteration in the river channel as predictor variables. As no predictors explained the variation in ecological status within the large size river class $\left(>1000 \mathrm{~km}^{2}\right)$, probably due to the low number of sites, we further combined all agricultural land use classes for large rivers $\left(>1000 \mathrm{~km}^{2}\right)$ to examine the effect of forested buffer zones on large rivers. As we wanted to study how a priori selected predictors explain variation in ecological status, we included all selected predictors in the RF analysis and did not fit the models. RF models performance were evaluated based on the Out-Of-Bag (OOB) percent variance explained.

The R package 'randomForest' (Liaw and Wiener 2002) and the functions randomForest, varImpPlot, and partialPlot were used to conduct the actual modelling and draw the variable importance plots and partial dependency plots, respectively.

\section{Results}

Most of the river water bodies examined were classified in good ecological status (47\%), followed by moderate (36\%), poor (10\%), high (4\%), and bad status classes (3\%) (Fig. S1). The mean forest cover in the 50-m adjacent riparian zone varied from 30 to $66 \%$ in the different classes. Forest percentage was highest for small streams with low amounts of agricultural land use in the catchment, and forest percentage was lowest in medium size streams with high amounts of agricultural land use in the catchment. As expected, ecological status was highest in the low agricultural impact stream classes and lowest in the classes with more than $20 \%$ agriculture in the catchment area.

The random forest model, with agricultural field cover, forest cover of entire catchments, the 50-m forest buffer zone and hydromorphological alteration as predictors, explained more variation (15.6 to $27.2 \%)$ in ecological status in small rivers $\left(<100 \mathrm{~km}^{2}\right)$ 
than in medium rivers $\left(100-1000 \mathrm{~km}^{2}\right)(5.5-8.7 \%)$ (Table 1) (Fig. 2). The area of the forested buffer zone was the most influential factor for ecological status in small rivers with intermediate agricultural land use pressure (10-20\%) and in medium rivers with intermediate and high (10-20\% and $>20 \%$ ) agricultural land use pressure (Fig. 2). Forested buffer zone was the second-most influential variable in small rivers that had high (>20\%) and low $(<10 \%)$ agricultural land use pressures (Table 1) (Fig. 3). Forested buffer zones did not account for the variation in ecological status of large rivers $\left(>1000 \mathrm{~km}^{2}\right)$ (Table 1). In large rivers, the percentage of agricultural fields and hydromorphological alteration explained most of the variation in ecological status. In small to medium rivers with $>10 \%$ agricultural land use, ecological status increased with an increasing proportion of forest buffer zones, indicating that increasing forest cover in buffer zones increased the ecological status of the river. The independent effect of forest buffer zones seemed to be strongest for intermediate agricultural land use classes (Fig. 2). Overall, the ecological status increased by almost one class when the forest cover in the buffer areas increased from 10 to $60 \%$.

Although we controlled for the agricultural pressure levels by the a priori classification, field percentage was still influential in small and medium rivers (Table 1) (Fig. S1). Ecological status decreased with an increasing percentage of agricultural fields in the catchment and with increasing levels of hydromorphological alterations. The individual influence of the hydromorphological alteration was minor for all river classes (Fig. S2). Also the individual influence of forest coverage of entire catchment was moderate (Fig. S3).

\section{Discussion}

Despite increasing concern about the impairment of freshwater ecosystems and the urgently required mitigation efforts (Wohl and AG 2018; Cantonati et al. 2020), empirical evidence on the effectiveness of current adjacent forested areas in reducing adverse effects on river ecosystems is still scarce. This study explored national WFD assessment data and showed that adjacent forested land indeed had a positive independent effect on the ecological status of agricultural streams. The effects were most pronounced in the groups of small and medium sized rivers, where adjacent forest cover increases from approximately 10 to $60 \%$ resulted in an improvement in ecological status by almost one status class.

Table 1 Summary of Random Forest (RF) models describing relationships between ecological status and stressors within each of the three river size classes $\left(<100 \mathrm{~km}^{2}, 100-1000 \mathrm{~km}^{2}\right.$, and $\left.>1000 \mathrm{~km}^{2}\right)$ and within each of the three agricultural pressure classes $(<10 \%, 10-20 \%$, and $>20 \%$ agriculture in catchment area). \% var $=\%$ variation accounted for by the model in each land use class. Predictor variables are listed from left to right in order of importance in the model. $n=$ number of classified rivers. Due to the low number of sites, all agricultural pressure classes are combined in the $>1000 \mathrm{~km}^{2}$ river size classes

\begin{tabular}{llll}
\hline Catchment size and agricultural cover & \% var & $n$ & Predictors \\
\hline Catchment $<100 \mathrm{~km}^{2},<10 \%$ Field & 15.6 & 211 & FIELDSca, FOREST50, FORESTca, HyMo \\
Catchment $<100 \mathrm{~km} 2,10-20 \%$ Field & 22.4 & 82 & FOREST50, FIELDSca, FORESTca, HyMo \\
Catchment $<100 \mathrm{~km}^{2},>20 \%$ Field & 27.2 & 44 & FIELDSca, FOREST50, FORESTca, HyMo \\
Catchment $100-1000 \mathrm{~km}^{2},<10 \%$ Field & 8.7 & 306 & FIELDSca, FORESTca, FOREST50, HyMo, \\
Catchment $100-1000 \mathrm{~km}^{2}, 10-20 \%$ Field & 5.5 & 99 & FOREST50, FIELDSca, FORESTca, HyMo \\
Catchment $100-1000 \mathrm{~km}^{2},>20 \%$ Field & 7.8 & 107 & FOREST50, FIELDSca, FORESTca, HyMo \\
Catchment $>1000 \mathrm{~km}^{2}$ & 32.7 & 75 & FIELDSca, HyMo, FOREST50, FORESTca \\
\hline
\end{tabular}




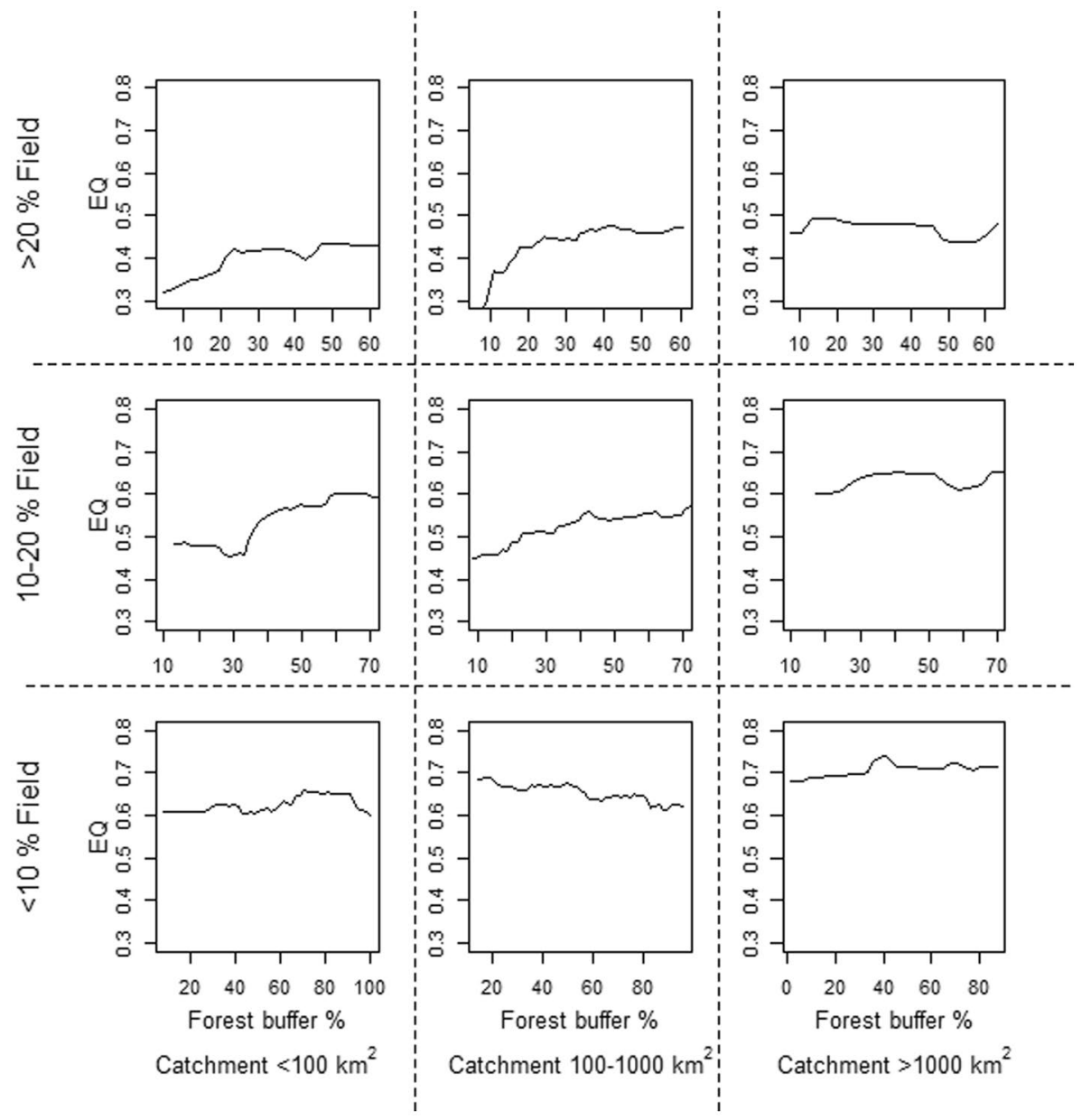

Fig. 2 Partial dependency plots from the Random Forest analysis showing the relationships between ecological quality status (EQ) and forested land adjacent to a river stretch (forest buffer \%) for the three river size classes $\left(<100 \mathrm{~km}^{2}, 100-1000 \mathrm{~km}^{2}\right.$, and $\left.>1000 \mathrm{~km}^{2}\right)$ and the three agricultural pressure classes $(<10 \%$, $10-20 \%$, and $>20 \%$ agriculture in catchment area). The plots characterize the average individual effects of forested buffer on the EQ after the effects of other predictor variables (Fig. 3) were accounted for. The $\mathrm{y}$-axis values thus do not represent the raw data. Ecological status $(\mathrm{bad}=0.1$, poor $=0.3$, moderate $=0.5$, $\operatorname{good}=0.7$, and high $=0.9$ )

The positive effect of riparian buffer zones has already been supported by evidence from smaller-scale studies. Studies addressing riparian zones have typically reported a positive relationship between biodiversity and forest cover percentage adjacent to a stream (e.g., Grizzetti et al. 2017; Turunen et al. 2019; Forio et al. 2020). These previous results are parallel to our novel findings from the large nationwide assessment dataset. One explanation for why the importance of adjacent forests depends on river size is that small streams are more strongly associated with the riparian zone than large rivers (Allan and Castillo 2007); therefore, small streams are more likely to suffer from anthropogenic changes in the riparian zone (Tolkkinen et al. 2020). Catchment-scale pressures in larger 


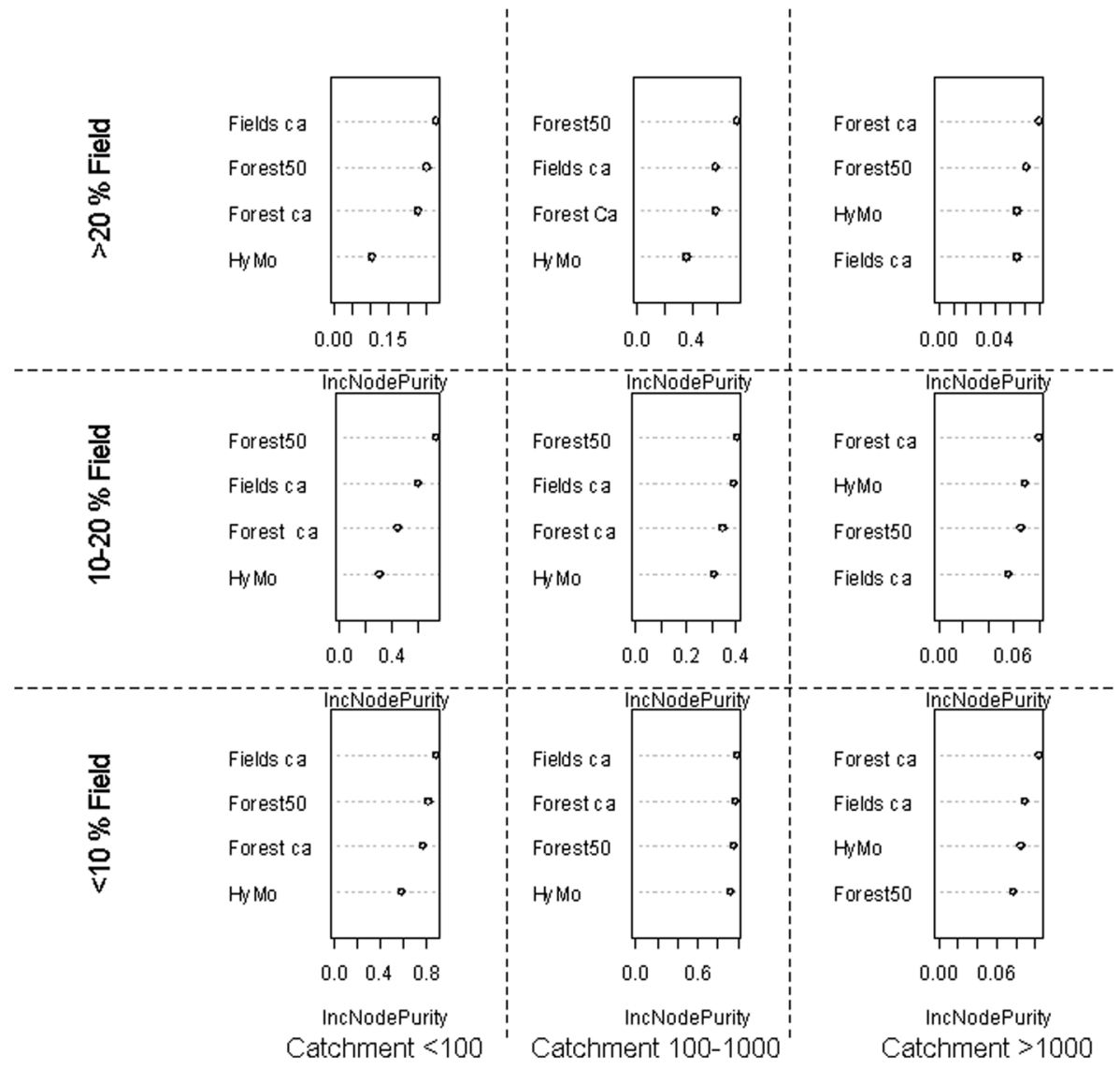

Fig. 3 Variable importance plots based on node purity for ecological status for the three river size classes $\left(<100 \mathrm{~km}^{2}, 100-1000 \mathrm{~km}^{2}\right.$, and $\left.>1000 \mathrm{~km}^{2}\right)$ and three agricultural pressure classes $(<10 \%, 10-20 \%$, and $>20 \%$ agriculture in catchment area)

rivers may overwhelm any positive effects of local riparian management, including the potential of forested zones for river management efforts (Burdon et al. 2020). Therefore, local management actions are often seen as most effective in small streams (Craig et al. 2008; Greenwood et al. 2012). Moreover, restoring and protecting headwater streams not only have positive local effects but also may enhance the ecological status of downstream reaches in larger rivers (Greenwood et al. 2012). The effect of forested zones on ecological status in this study could have been even stronger if forested buffer zones were actively used in the management of agricultural watersheds. Therefore, enhancing forested buffers as an effective management tool would require the implementation of more extensive and continuous buffer zones in agricultural watersheds.

Negative effects of agriculture on stream ecosystems through increased inputs of nutrients and contaminants have been detected both in broad-scale assessments and small-scale surveys (e.g., Moss 2008; Tolkkinen et al. 2013; Reid et al. 2019). This common finding is in line with what was detected in this study; i.e., agricultural land use was negatively associated with ecological status in a river assessment. In addition to agriculture, river 
hydromorphological alterations also had negative effects on ecological status in this study, supporting previous findings that hydromorphological alteration has negative impacts on river ecological quality (e.g., Negishi et al. 2002; Wyzga et al. 2012; Grizzetti et al. 2017). However, the independent effect of hydromorphological alteration was generally low in this study, and other variables surpassed its importance to ecological status. Hydromorphological alteration accounted for some of the variation in the ecological status of large rivers, especially those that are more heavily modified and under ongoing water management actions. One explanation for why we saw only low hydromorphological effects is that hydromorphological degradation in small and medium size rivers may not be that detrimental to near-bed characteristics; thus, suitable habitats remain for most organisms (Muotka and Syrjänen 2007). Nevertheless, disentangling the effects of hydromorphological alteration and catchment land use is challenging in the context of agricultural streams that are often also hydromorphologically strongly modified.

\section{Conclusions}

This study has major implications for achieving the WFD goal of rivers with good ecological status levels. The expected positive effect of riparian forests on ecological status in this study provides an important guideline for authorities responsible for river basin management. Considering the efficacy of riparian forested buffers to ecological status at large spatial scales, it is highly likely that forested buffers are highly relevant to the management of agricultural river catchments across entire nations. The results emphasize the importance of adequate management actions in both the entire catchment and riparian areas. In this context, this paper highlights that small streams will specifically benefit from the protection and restoration of their forested buffer zones, whereas overall catchment land use may override the role of forested zones in large rivers. Thus, protecting and restoring headwater riparian zones are likely to have advantages for ecological quality further downstream as well. Because land-use intensification is an ongoing trend, there is a strong need to restore and protect freshwater ecosystems and organisms in agricultural landscapes (e.g., Stoate et al. 2009; Hill et al. 2019). Therefore, the positive independent effect that forested buffer zones can have on river ecological status is an important message to environmental managers and policy makers.

Supplementary Information The online version contains supplementary material available at https://doi. org/10.1007/s11269-021-02923-2.

Acknowledgements We would like to thank Dr. Jani Heino for help of material preparation, data collection and valuable comments. This study was funded by the Nordic Centre of Excellence "BIOWATER" (Nordforsk Project no. 82263) and by the Ministry of Agriculture and Forestry as part of the monitoring network MaaMet.

Author Contribution All authors contributed to the study conception and design. Material preparation and data collection were performed by Mikko Tolkkinen, Saku Vaarala and Jukka Aroviita. Analysis were performed by Mikko Tolkkinen, and Jukka Aroviita. The first draft of the manuscript was written by Mikko Tolkkinen. All authors commented on previous versions of the manuscript. All authors read and approved the final manuscript.

Funding Open access funding provided by Finnish Environment Institute (SYKE). This study was funded by the Nordic Centre of Excellence "BIOWATER" (Nordforsk Project no. 82263) and by the Ministry of Agriculture and Forestry as part of the monitoring network MaaMet. 
Data Availability Data are available at the public database (https://www.syke.fi/en-US/Open_information).

Code Availability All analyses were made by open software R.

\section{Declarations}

Ethics Approval Not applicable.

Consent to Participate Authors give their permission.

Consent to Publish Authors give their permission.

Competing Interests The authors declare no conflicts of interest.

Open Access This article is licensed under a Creative Commons Attribution 4.0 International License, which permits use, sharing, adaptation, distribution and reproduction in any medium or format, as long as you give appropriate credit to the original author(s) and the source, provide a link to the Creative Commons licence, and indicate if changes were made. The images or other third party material in this article are included in the article's Creative Commons licence, unless indicated otherwise in a credit line to the material. If material is not included in the article's Creative Commons licence and your intended use is not permitted by statutory regulation or exceeds the permitted use, you will need to obtain permission directly from the copyright holder. To view a copy of this licence, visit http://creativecommons.org/licenses/by/4.0/.

\section{References}

Allan J, Castillo M (2007) Stream Ecology, Structure and Function of Running Waters, 2nd edition. Springer, Netherlands, p 444

Aroviita J, Mitikka S, Vienonen S (2019) Pintavesien tilan luokittelu ja arviointiperusteet vesienhoidon kolmannella kaudella. Suom Ympäristökeskuksen Raportteja 37:182

Birk S, Bonne W, Borja A, Brucet S, Courrat A, Poikane S, Solimini A, van de Bund WV, Zampoukas N, Hering D (2012) Three hundred ways to assess Europe's surface waters: an almost complete overview of biological methods to implement the water framework directive. Ecol Ind 18:31-41

Breiman L (2001) Random forests. Mach Learn 45:5-32

Burdon FJ, Ramberg E, Sargac J, Forio MAE, de Saeyer N, Mutinova PT, Moe TF, Pavelescu MO, Dinu V, Cazacu C, Witing F, Kupilas B, Grandin U, Volk M, Risnoveanu G, Goethals P, Friberg N, Johnson RK, McKie BG (2020) Assessing the benefits of forested riparian zones: a qualitative index of riparian integrity is positively associated with ecological status in European streams. Water 12

Cantonati M, Poikane S, Pringle CM, Stevens LE, Turak E, Heino J, Richardson JS, Bolpagni R, Borrini A, Cid N, Ctvrtlikova M, Galassi DMP, Hajek M, Hawes I, Levkov Z, Naselli-Flores L, Saber AA, Di Cicco M, Fiasca B, Hamilton PB, Kubacka J, Segadelli S, Znachor P (2020) Characteristics, main impacts, and stewardship of natural and artificial freshwater environments: consequences for biodiversity conservation. Water 12

Craig LS, Palmer MA, Richardson DC, Filoso S, Bernhardt ES, Bledsoe BP, Doyle MW, Groffman PM, Hassett BA, Kaushal SS, Mayer PM, Smith SM, Wilcock PR (2008) Stream restoration strategies for reducing river nitrogen loads. Front Ecol Environ 6:529-538

Cole LJ, Stockan J, Helliwell R (2020) Managing riparian buffer strips to optimise ecosystem services: a review. Agric Ecosyst Environ 296

Davies B, Biggs J, Williams P, Thompson S (2009) Making agricultural landscapes more sustainable for freshwater biodiversity: a case study from southern England. Aquat Conserv Mar Freshw Ecosyst 19:439-447

Death RG, Collier KJ (2010) Measuring stream macroinvertebrate responses to gradients of vegetation cover: when is enough enough? Freshw Biol 55:1447-1464

Ecological Status and Corine Land Cover: Finnish Environment Institute (2021) https://www.syke.fi/en-US/ Open_information/Spatial_datasets. Accessed 10 Jan 2021 
Feld CK, Fernandes MR, Ferreira MT, Hering D, Ormerod SJ, Venohr M, Gutierrez-Canovas C (2018) Evaluating riparian solutions to multiple stressor problems in river ecosystems - a conceptual study. Water Res 139:381-394

Flavio HM, Ferreira P, Formigo N, Svendsen JC (2017) Reconciling agriculture and stream restoration in Europe: a review relating to the EU water framework directive. Sci Total Environ 596:378-395

Forio MAE, De Troyer N, Lock K, Witing F, Baert L, Saeyer ND, Rîşnoveanu G, Popescu C, Burdon FJ, Kupilas B (2020) Small patches of riparian Woody vegetation enhance biodiversity of invertebrates. Water 12:3070

Greenwood MJ, Harding JS, Niyogi DK, McIntosh AR (2012) Improving the effectiveness of riparian management for aquatic invertebrates in a degraded agricultural landscape: stream size and land-use legacies. J Appl Ecol 49(1):213-222

Grizzetti B, Pistocchi A, Liquete C, Udias A, Bouraoui F, van de Bund W (2017) Human pressures and ecological status of European rivers. Sci Rep 7:205

Hill MJ, Heino J, White JC, Ryves DB, Wood PJ (2019) Environmental factors are primary determinants of different facets of pond macroinvertebrate alpha and beta diversity in a human-modified landscape. Biol Cons 237:348-357

Johnson RK, Almlöf K (2016) Adapting boreal streams to climate change: effects of riparian vegetation on water temperature and biological assemblages. Freshw Sci 35(3):984-997

Jones EBD, Helfman GS, Harper JO, Bolstad PV (1999) Effects of riparian forest removal on fish assemblages in southern Appalachian streams. Conserv Biol 13:1454-1465

Kiffney PM, Richardson JS, Bull JP (2003) Responses of periphyton and insects to experimental manipulation of riparian buffer width along forest streams. J Appl Ecol 40:1060-1076

Lammert M, Allan JD (1999) Assessing biotic integrity of streams: effects of scale in measuring the influence of land use/cover and habitat structure on fish and macroinvertebrates. Environ Manage 23:257-270

Liaw A, Wiener M (2002) Classification and regression by randomForest. R News 2:18-22

Moss B (2008) Water pollution by agriculture. Philos Trans Roy Soc B: Biol Sci 363:659-666

Muotka T, Syrjänen J (2007) Changes in habitat structure, benthic invertebrate diversity, trout populations and ecosystem processes in restored forest streams: a boreal perspective. Freshw Biol 52(4):724-737

Naiman RJ, Decamps H, McClain ME (2010) Riparia: ecology, conservation, and management of streamside communities. Elsevier

Nakano S, Murakami M (2001) Reciprocal subsidies: dynamic interdependence between terrestrial and aquatic food webs. Proc Natl Acad Sci USA 98:166-170

Negishi JN, Inoue M, Nunokawa M (2002) Effects of channelisation on stream habitat in relation to a spate and flow refugia for macroinvertebrates in northern Japan. Freshw Biol 47:1515-1529

Pavlidis G, Tsihrintzis VA (2018) Environmental benefits and control of pollution to surface water and groundwater by agroforestry systems: a review. Water Resour Manage 32:1-29

Perkins DM, Reiss J, Yvon-Durocher G, Woodward G (2010) Global change and food webs in running waters. Hydrobiologia 657:181-198

Poikane S, Birk S, Bohmer J, Carvalho L, de Hoyos C, Gassner H, Hellsten S, Kelly M, Solheim AL, Olin M, Pall K, Phillips G, Portielje R, Ritterbusch D, Sandin L, Schartau AK, Solimini AG, van den Berg M, Wolfram G, van de Bund W (2015) A hitchhiker's guide to European lake ecological assessment and intercalibration. Ecol Ind 52:533-544

Reid AJ, Carlson AK, Creed IF, Eliason EJ, Gell PA, Johnson PT, Kidd KA, MacCormack TJ, Olden JD, Ormerod SJ (2019) Emerging threats and persistent conservation challenges for freshwater biodiversity. Biol Rev 94:849-873

Singh R, Tiwari AK, Singh GS (2021) Managing riparian zones for river health improvement: an integrated approach. Landscape Ecol Eng 17:195-223

Soininen J, Bartels P, Heino J, Luoto M, Hillebrand H (2015) Toward more integrated ecosystem research in aquatic and terrestrial environments. Bioscience 65:174-182

Sponseller RA, Benfield EF, Valett HM (2001) Relationships between land use, spatial scale and stream macroinvertebrate communities. Freshw Biol 46:1409-1424

Stoate C, Baldi A, Beja P, Boatman ND, Herzon I, van Doorn A, de Snoo GR, Rakosy L, Ramwell C (2009) Ecological impacts of early 21 st century agricultural change in Europe - a review. J Environ Manage 91:22-46

Stutter MI, Chardon WJ, Kronvang B (2012) Riparian buffer strips as a multifunctional management tool in agricultural landscapes: introduction. J Environ Qual 41:297-303

Thomas SM, Griffiths SW, Ormerod SJ (2016) Beyond cool: adapting upland streams for climate change using riparian woodlands. Glob Change Biol 22:310-324 
Tolkkinen M, Mykrä H, Markkola A-M, Aisala H, Vuori K-M, Lumme J, Pirttilä AM, Muotka T (2013) Decomposer communities in human-impacted streams: species dominance rather than richness affects leaf decomposition. J Appl Ecol 50:1142-1151

Tolkkinen MJ, Heino J, Ahonen SHK, Lehosmaa K, Mykra H (2020) Streams and riparian forests depend on each other: a review with a special focus on microbes. For Ecol Manage 462

Turunen J, Elbrecht V, Steinke D, Aroviita J (2021) Riparian forests can mitigate warming and ecological degradation of agricultural headwater streams. Freshw Biol 2021(00):1-14

Turunen J, Markkula J, Rajakallio M, Aroviita J (2019) Riparian forests mitigate harmful ecological effects of agricultural diffuse pollution in medium-sized streams. Sci Total Environ 649:495-503

Vannote RL, Minshall GW, Cummins KW, Sedell JR, Cushing CE (1980) The river continuum concept. Can J Fish Aquat Sci 37:130-137

Wahl CM, Neils A, Hooper D (2013) Impacts of land use at the catchment scale constrain the habitat benefits of stream riparian buffers. Freshw Biol 58:2310-2324

Warren DR, Keeton WS, Kiffney PM, Kaylor MJ, Bechtold HA, Magee J (2016) Changing forests-changing streams: riparian forest stand development and ecosystem function in temperate headwaters. Ecosphere 7

WFD, European Commission (2000) http://ec.europa.eu/environment/water/water-framework/index_en. html. Accessed 10 Jan 2021

Wohl E, Springer International Publishing AG (2018) Sustaining river Ecosystems and water resources. Springer International Publishing

Wyzga B, Oglecki P, Radecki-Pawlik A, Skalski T, Zawiejska J (2012) Hydromorphological complexity as a driver of the diversity of benthic invertebrate communities in the Czarny Dunajec River, Polish Carpathians. Hydrobiologia 696:29-46

Zhao QY, Hastie T (2021) Causal Interpretations of black-box models. J Bus Econ Stat 39:272-281

Publisher's Note Springer Nature remains neutral with regard to jurisdictional claims in published maps and institutional affiliations. 